\title{
Fish Occurrence Database of the Family Aphaniidae
}

Baran Yogurtcuoglu (iD) \& Joerg Freyhof (i)
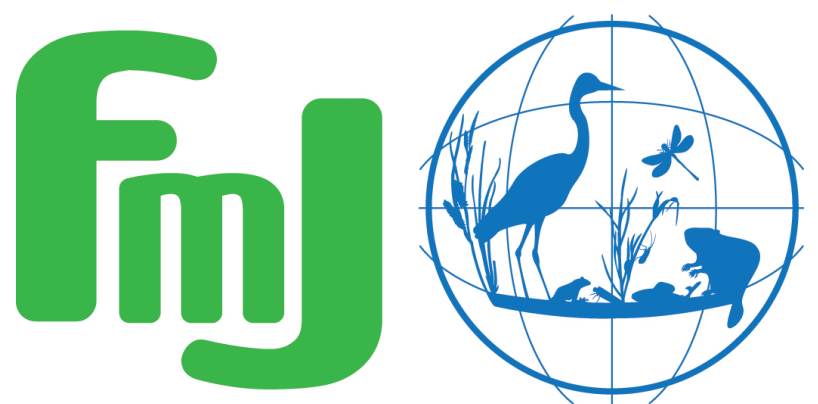

Freshwater Metadata Journal 



\title{
Fish Occurrence Database of the Family Aphaniidae
}

\author{
Baran Yogurtcuoglu ${ }^{1}$ (iD) \& Joerg Freyhof ${ }^{2}$ \\ 1 Hacettepe University, Ankara, Turkey; corresponding author: yokbaran@gmail.com \\ 2 Museum fur Naturkunde, Berlin, Germany
}

Please cite this paper as follows: Yogurtcuoglu, B. \& Freyhof, J., 2020. Fish Occurrence Database of the Family Aphaniidae. Freshwater Metadata Journal 48: 1-5. https://doi.org/10.15504/fmj.2020.48

Received: 2020-06-12 / Published: 2020-06-16

\section{Keywords}

Aphaniidae, Taxonomy, Site Records, GBIF

\section{Short description of the dataset/summary}

The database contains 1064 geo-referenced distribution data of fish species of all genera within the family Aphaniidae. The data has been partially downloaded from GBIF, and has been quality checked and is now being uploaded again by providing additional data from published scientific and grey literature as well as from site scale records.

\section{General information}

dataset entry ID:

name of the dataset:

full name of the dataset:

full name of the datast (original/national language):

Fish Occurrence Database of the Family Aphaniidae

dataset short name:

type of dataset:

data type:

science keywords according to GCMD:

topic:

SO topic category according to ISO 19115:

Biota, Geoscientific Information, Inland Waters, Location

INSPIRE keywords according to GEMET:

Fish Database Family Aphaniidae

species distribution data

point data/observation data

Species distribution

own science keywords:

Aphaniidae, taxonomy, site records, GBIF 


\section{Technical and administrative specifications}

$\begin{array}{ll}\text { data format: } & \text { Excel } \\ \quad \text { others/details: } & \text { type of file: Microsoft Excel worksheet (.xlsx) } \\ \text { operating system: } & \text { all Windows systems } \\ \text { data language: } & \text { English } \\ \text { current access level: } & \text { internal } \\ \quad \text { currently available through GBIF: } & \text { yes } \\ \text { exchange planned: } & \text { yes } \\ \text { data in data repository: } & \text { no }\end{array}$

Do you plan to publish the data on the Freshwater Biodiversity Data Portal:

$\begin{array}{ll}\text { update level: } & \text { continuously updated } \\ \text { documentation: } & \\ \text { type: } & \text { manual } \\ \text { language: } & \text { English } \\ \text { specify: } & \text { The dataset in Excel is in English. }\end{array}$

\section{contact details:}

metadata contact person:

first, last name:

Baran Yogurtcuoglu

phone:

+90-0-312-297-8039

email:

yokbaran@gmail.com

institution:

Hacettepe University

address:

postal code, city:

Department of Biology, Beytepe

06800 Ankara

province, state:

Çankaya

country

Turkey

web address:

http://www.biology.hacettepe.edu.tr/tr/doc dr baran yogurtcuoglu-96

technical contact person:

first, last name:

Baran Yogurtcuoglu

phone:

+90-0-312-297-8039

email:

yokbaran@gmail.com

scientific contact person:

first, last name:

Baran Yogurtcuoglu

phone:

+90-0-312-297-8039

email:

yokbaran@gmail.com

\section{Intellectual property rights and citation}

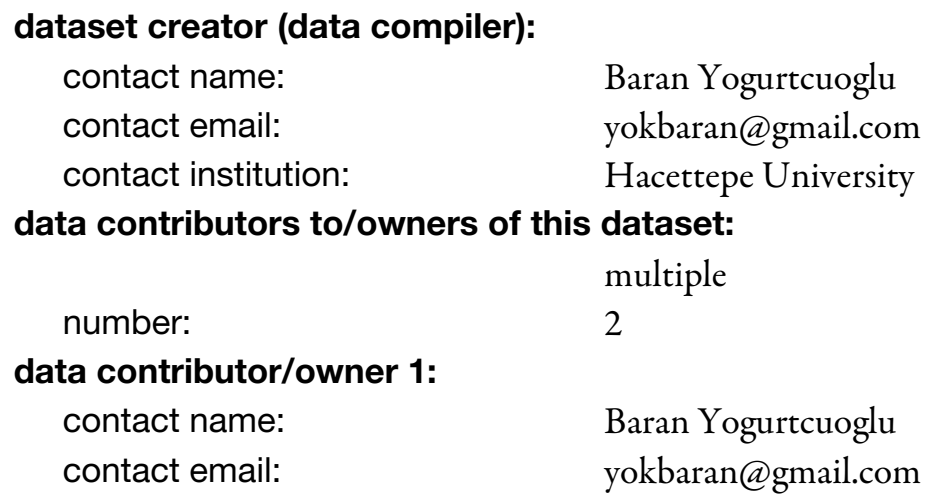


contact institute:

criteria for using this part of the dataset:

Hacettepe University

The dataset is publicly available (data portal, data archive) and can be used without restrictions, but dataset creator/data contributors must be informed prior to publication. Data must be acknowledged and cited correctly.

data contributor/owner 2:

contact name:

Joerg Freyhof

contact email:

Joerg.Freyhof@mfn.berlin

contact institute:

Museum fuer Naturkunde

criteria for using this part of the dataset:

The dataset is publicly available (data portal, data archive) and can be used without restrictions, but dataset creator/data contributors must be informed prior to publication. Data must be acknowledged and cited correctly.

\section{citation of this dataset:}

author(s):

Yogurtcuoglu, B. \& Freyhof, J.

title and journal (name, number, pages):

Fish Occurrence Database of the Family Aphaniidae. Published to GBIF via the BioFresh IPT.

year: $\quad 2020$

doi: $\quad$ https://doi.org/10.15468/mqbnga

\section{citation of the metadata:}

author(s):

Yogurtcuoglu B. \& Freyhof J.

title and journal (name, number, pages):

Fish Occurrence Database of the Family Aphaniidae. Freshwater Metadata Journal 48: 1-5

year: $\quad 2020$

doi: $\quad$ https://doi.org/10.15504/fmj.2020.48

\section{General data specifications}

\section{regional coverage of the dataset:}

spatial extent of the dataset:

global

continents:

Africa, Asia, Europe

\section{spatial extent (bounding coordinates):}

southernmost latitude $\left[^{\circ}\right]$ :

7.966667

northernmost latitude $\left[^{\circ}\right]$ :

45.7833333

westernmost longitude $\left[^{\circ}\right]$ :

$-6.9671360$

easternmost longitude $\left[^{\circ}\right]$ :

69.7174000

countries:

Africa: Algeria, Djibouti, Egypt, Eritrea, Ethiopia, Libya, Morocco, Somalia,

Sudan, Tunisia, Somaliland

Asia: Bahrain, Cyprus, India, Iran, Iraq, Israel, Jordan, Kuwait, Lebanon, Oman,

Palestinian territories, Saudi Arabia, Syria, Turkey, United Arab Emirates,

Yemen

Europe: Albania, Croatia, France, Greece, Italy, Malta, Montenegro, Slovenia, Spain

freshwater ecoregions of the world (FEOW) according to WWF:

Africa: Dry Sahel, Ethiopian Highlands, Horn of Africa, Lower Nile,

Mediterranean Northwest Africa, Nile Delta, Northern Eastern Rift, Sahara,

Western Red Sea Drainages 
ecosystem type: covered timeframe: comments:

\section{Site specifications}

coordinate system/grid data: datum (e.g. WGS84):

grid data available:

number of sites:

\section{Biological data}

biological data origin:

comments:

organism group addressed:
Asia: Baluchistan, Lower \& Middle Indus

Europe: Aegean Drainages, Arabian Interior, Atlantic Northwest Africa, Caspian Highlands, Central Anatolia, Coastal Levant, Dalmatia, Eastern Iberia, Esfahan, Gulf of Venice Drainages, Ionian Drainages, Italian Peninsula \& Islands, Jordan River, Kavir \& Lut Deserts, Lower Tigris \& Euphrates, Namak, Northern Anatolia, Northern Hormuz Drainages, Oman Mountains, Orontes, Orumiyeh, Sinai, Southern Anatolia, Southern Iberia, Southwestern Arabian Coast, Thrace, Upper Tigris \& Euphrates, Vardar, Western Anatolia rivers, lakes/ponds, wetlands, general freshwater, coastal areas $1877-2020$

there are also records without date

latitude/longitude, format: DD

WGS84

no

$100-1000$

from sampling, international \& national projects general compilation, literature survey Some of the data that come from sampling have been collected by national and international projects that were funded by ministries, research institutes or universities.

fish

species

100

Freyhof \& Yogurtcuoglu (2020)

Freyhof, J. \& Yogurtcuoglu, B. (2020): A proposal for a new generic structure of the killifish family Aphaniidae with the description of Aphaniops teimorii (Teleostei: Cyprinodontiformes). Zootaxa (in press).

sample specifications:

\section{Other specifications}

GIS layers, shape files related to the dataset:

availability of maps:

no data available

yes 


\section{quality control procedures:}

Were any quality control procedures applied to your dataset?

yes

quality control protocols and comments:

Many of the occurrence data were controlled by the barcoding results of Geiger et al. (2014) as well as our own unpublished molecular data.

reference(s): Geiger, M.F., Herder, F., Monaghan, M.T., Almada, V., Barbieri, R., Bariche, M., Berrebi, P., Bohlen, J., Casal-Lopez, M., Delmastro, G.B., Denys, G.P.J., Dettai, A., Doadrio, I., Kalogianni, E., Kärst, H., Kottelat, M., Kovacic, M., Laporte, M., Lorenzoni, M., Marcic, Z., Özulug, M., Perdices, A., Perea, S., Persat, H., Porcelotti, S., Puzzi, C., Robalo, J., Sanda, R., Schneider, M., Slechtova, V., Stoumboudi, M., Walter, S. \& Freyhof, J. (2014): Spatial heterogeneity in the Mediterranean Biodiversity Hotspot affects barcoding accuracy of its freshwater fishes. Molecular Ecology Resources 14, 1210-1221.

\section{References}

Freyhof, J. \& Yogurtcuoglu, B., 2020. A proposal for a new generic structure of the killifish family Aphaniidae, with the description of Aphaniops teimorii (Teleostei: Cyprinodontiformes). Zootaxa. (in press) https://doi.org/NN 
Appendix 


\section{References used in occurrence dataset in the Aphaniidae Database}

Akşıray F. 1948. Türkiye Cyprinodontidleri hakkında I. Türkische Cyprinodontiden I. Revue de la Faculté des Sciences de I'Université d'Istanbul 13: 97-142.

Alavi-Yeganeh M., Keivany Y., Seyfabadi J., Kazemi B. \& Wallis G. 2014. Taxonomic validity and phylogenetic relationships of a newly-described tooth-carp, Aphanius mesopotamicus Coad, 2009 (Teleostei: Cyprinodontidae). Zootaxa 3780: 594-600.

Alavi-Yeganeh M.S., Seyfabadi J., Keivany Y. Kazemi B. \& Wallis G. 2011. Length-weight relationships in some populations and species of Iranian toothcarps. Journal of Applied Ichthyology 27: 1401-1403.

Annabi A., Ben Faleh A., \& Said K. 2013. Preliminary study of the genetic differentiation among natural populations of Mediterranean killifish Aphanius fasciatus (Teleostei, Cyprinodontidae). American Journal of Research Communication 1: 110-125.

Anonymous 1997. Fish registrations within the museum database of the Vertebrate Section of the Royal Museum for Central Africa. MRAC, Tervuren, Belgium.

Bardakçı F., Tatar N. \& Hrbek T. 2004. Genetic relationships between Anatolian species and subspecies of Aphanius Nardo, 1827 (Pisces, Cyprinodontiformes) based on RAPD markers. Biologia, Bratislava 59: 559-566.

Bibak M. Abbas S. Koohani, M. \& Daliri M. 2012. Length-weight and length-length relationships of Aphanius dispar dispar (Ruppell, 1829) in Dalaki river, Bushehr, in south of i̇ran. Scientific Research and Essays 7: 969-971

Blanco J.L., Hrbek T. \& Doadrio, I. 2006. A new species of the genus Aphanius (Nardo, 1832) (Actinopterygii, Cyprinodontidae) from Algeria. Zootaxa 1158: 39-53.

Buj I., Miočić-Stošić J., Marčić Z., Mustafić P., Zanella D., Mrakovčić M. \& Ćaleta M. 2015. Population genetic structure and demographic history of Aphanius fasciatus (Cyprinodontidae:Cyprinodontiformes) from hypersaline habitats in the eastern Adriatic. Scientia Marina 79: 399-408.

Chaibi R., Si Bachir A., \& Chenchouni H. 2015. New inland sites for the Mediterranean Killifish (Aphanius fasciatus Valenciennes, 1821) in the Sahara Desert of Algeria. Journal of Applied Ichthyology 31: 1072-1076. 
Chiozzi G., Stiassny M.J.L., Alter S.E., De Marchi G. Mebrahtu Y., Tessema M., Asmamaw B., Fasola M. \& Bellati A. 2018. Fishes in the desert: mitochondrial variation and phylogeography of Danakilia (Actinopterygii: Cichlidae) and Aphanius. Mitochondrial DNA Part A 29: 1025-1040

Deidun A., Arcidiacono I., Tigano C. \& Schembri P.J. 2002. Present distribution of the threatened killifish Aphanius fasciatus. (Actinopterygii, Cyprinodontidae) in the Maltese islands. The Central Mediterranean Naturalist 3: 177-180.

Doadrio I. 2001. Atlas y libro rojo de los peces continentales de España. Consejo Superior de Investigaciones Científicas (CSIC). 364 pp.

Ekmekçi F.G. \& Yoğurtçuoğlu B. 2014. Endemik bir balik turu ile istilaci bir balik turunun Sakarya Havzasi'ndaki dagilimlarinin belirlenmesi [in Turkish] (Report no. 013 D05 601 007) Hacettepe University, Scientific Research Projects Unit.

Elp M., Atıcı A.A., Şen F. \& Duyar A.H. 2016. Van Gölü Havzası balıkları ve yayılım bölgeleri. Yüzüncü Yil Üniversitesi Tarim Bilimleri Dergisi 26: 563-568

Embarek R., Amara R. \& Kara M.H. 2017. Fish assemblage structure in shallow waters of the Mellah Lagoon (Algeria): Seasonal and spatial distribution patterns and relation to environmental parameters. Acta ichthyologica et Piscatoria 47: 133-144.

Embarek R., Kara M.H., Bahri-Sfar L. \& Amara R. 2019. Seasonal and spatial variations in the fish assemblage of shallow habitats within the Bizerte lagoon (Tunisia). Vie et milieu - Life and environment 69: 35-46.

Ergüden S.A. \& Göksu M.Z.L. 2012. The Fish Fauna of the Seyhan Dam Lake (Adana). Journal of FisheriesSciences.com 6: 39-52

Erk'akan F. \& Özdemir F. 2011. Revision of the Fish Fauna of Seyhan and Ceyhan River Basins in Turkey. Research Journal of Biological Sciences 6: 1-8.

Esmaeili H.R., Teimori A., Zarei F. \& Sayyadzadeh G. 2020. DNA barcoding and species delimitation of the Old World tooth-carps, family Aphaniidae Hoedeman, 1949 (Teleostei: Cyprinodontiformes). PLOSONE 15: e0231717, https://doi.org/10.1371/journal.pone.0231717

Esmaeili H.R., Ebrahimi M. \& Saifali M. 2008. Karyological analysis of five tooth-carps (Actinopterygii: Cyprinodontidae) from Iran. Micron 39: 95-100.

Esmaeili H.R., Teimori A., Gholami Z. \& Reichenbacher B. 2014. Two new species of the toothcarp Aphanius (Teleostei: Cyprinodontidae) and the evolutionary history of the Iranian inland and inland-related Aphanius species. Zootaxa 3786: 246-268. 
Freyhof J., Özulug M. \& Saç, G. 2017. Neotype designation of Aphanius iconii, first reviser action to stabilise the usage of $A$. fontinalis and $A$. meridionalis and comments on the family group names of fishes placed in Cyprinodontidae (Teleostei:Cyprinodontiformes). Zootaxa 4294: $573-585$.

Freyhof J., Els J., Feulner G.R., Hamidan N.A., \& Krupp F. 2020. The Freshwater Fishes of the Arabian Peninsula. Dubai: Motivate Media Group, 257 pp.

Freyhof J., Weissenbacher A. \& Geiger M. 2017. Aphanius kruppi, a new killifish from Oman with comments on the $A$. dispar species group (Cyprinodontiformes: Aphaniidae). Zootaxa 4338: 557-573.

Gafouri Z., Keivany Y. \& Soofiani N. M. 2018. Reproductive biology of Aphanius isfahanensis in the Zayandehrud River, Central Iran. Environmental Biology of Fishes 102: 19-25.

Geiger M.F., Herder F., Monaghan M.T., Almada V., Barbieri R., Bariche M., Berrebi P., Bohlen J. Casal-Lopez M., Delmastro G.B., Denys G.P.J., Dettai A., Doadrio I., Kalogianni E., Kärst H., Kottelat M., Kovačić M., Laporte M., Lorenzoni M., Marčić Z., Özuluğ M., Perdices A., Perea S., Persat H. Porcelotti S., Puzzi C., Robalo J., Šanda R. Schneider M., Šlechtová V., Stoumboudi M., Walter S. \& Freyhof J. 2014. Spatial heterogeneity in the Mediterranean Biodiversity Hotspot affects barcoding accuracy of its freshwater fishes. Molecular Ecology Resources 14: $1210-1221$.

Gholami Z. 2014. Ecological plasticity and divergence processes of the Iranian inland species of Aphanius (Teleostei, Cyprinodontidae), with focus on A. sophiae and A. farsicus in the Kor River and Maharlu Lake basins, Southwestern Iran. PhD Dissertation, Munich.

Gholami Z., Esmaeili H.R., Erpenbeck D. \& Reichenbacher B. 2014. Phylogenetic analysis of Aphanius from the endorheic Kor River Basin in the Zagros Mountains, South-western iran (Teleosti: Cyprinodontiformes: Cyprinodontidae). Journal of Zoological Systematics and Evolutionary Research 52: 130-141.

Gianferrari L. 1932. Un nuovo Cyprinodon sirtico. Atti della Societa Italiana di Scienze Naturalie del Museo Civico di Storia Naturale di Milano 71: 214-216.

Gonzales E.G., Pedraza-Lara C. \& Doadrio I. 2014. Genetic diversity and population history of the endangered killifish Aphanius baeticus. Journal of Heredity 105: 597-610. 
Guezi R., Chaoui L. \& Kara M.H. 2017. Life history of the Mediterranean killifish Aphanius fasciatus in brackish water habitat of Algerian low Sahara. Environmental Biology of Fishes 100: 481491

Güçlü S.S., Küçük F., Ertan O.O. \& Güçlü Z. 2013. The Fish Fauna of the Buyuk Menderes River (Turkey): Taxonomic and Zoogeographic Features. Turkish Journal of Fisheries and Aquatic Sciences 13: 685-698.

Gülle I., Küçük F. \& Güçlü S.S. 2017. Re-description and new distribution area of an endemic Anatolian fish species, Alburnus nasreddini Battalgil, 1944. Turkish Journal of Fisheries and Aquatic Science 17: 863-869.

Hamidan N. \& Shobrak M. 2019. An update on freshwater fishes of Saudi Arabia. Jordan Journal of Biological Science 12: 495-502.

Hrbek T., Küçük F., Frickey T., Stölting K.N. Wildekamp R.H. \& Meyer A. 2002. Molecular phylogeny and historical biogeography of the Aphanius (Pisces, Cyprinodontiformes) species complex of central Anatolia, Turkey. Molecular Phylogenetics and Evolution 25: 125-137.

İlhan A., Balık S. \& Sarı H.M. 2014. Orta ve batı Anadolu endemik içsu balıklarının günümüzdeki dağılımı ve koruma statüleri [in Turkish]. Aquatic Sciences and Engineering 29: 9-34.

Jalali B., Soofiani M. N., Asadollah S., Barzegar M. 2012. An investigation on fish parasites in Hanna Wetland, Semirom, Isfahan Province. Iranian Scientific Fisheries Journal 21: 25-38.

Kara C., Alp A., Şimşekli M. 2010. Distribution of Fish Fauna on the Upper and Middle Basin of Ceyhan River, Turkey. Turkish Journal of Fisheries and Aquatic Sciences 10: 111-122

Keivany Y. \& Ghorbani M. 2012. Distribution of Aphanius dispar dispar (Ruppell, 1829) populations in Iran, with a new record from western Iran (Actinopterygii: Cyprinodontidae). Turkish Journal of Zoology 36: 824-827

Kessabi K., Navarro A., Casado M., Saïd K., Messaoudi I., \& Piña B. 2010. Evaluation of environmental impact on natural populations of the Mediterranean killifish Aphanius fasciatus by quantitative RNA biomarkers. Marine Environmental Research 70: 327-333.

Kessel C.M., Woeltjes T. \& Zee J.R. van der. 1985. De tandkarpers van het Middellandse Zee gebied (1). Het Aquarium 55: 154-159.

Kosswig C. 1953. Über die Verwandtschaftsbeziehungen anatolischer Zahnkarpfen. Hidrobiologi Hydrobiological Research Institute Faculty of Sciences University of Istanbul Ser. B 1: 186-198. 
Kottelat M., Barbieri R. \& Stoumboudi M.T. 2007. Aphanius almiriensis, a new species of toothcarp from Greece (Teleostei:Cyprinodontidae). Revue Suisse de Zoologie 114: 13-31.

Kraiem M.M. 1983. Les poissons d'eau douce de Tunisie: inventaire comment et repartition géographique. Bulletin deL'institut National Scientifique et Technique d'océanographie et de Pêche de Salammbô 10: 107-124.

Krupp F. \& Schneider W. 2008. Die Fischfauna des Nahr al-Khabur Nordost-Syrien. In: Umwelt und Subsistenz der assyrischen Stadt Dur-Katlimmu am unteren Habur. Hartmut Kühne (éd.) (Berichte der Ausgrabung Tell Seh Hammad/Dur-Katlimmu 8) Harrassowitz Wiesbaden 2008 $x x x+261 p$

Krupp F. 1983. Fishes of Saudi Arabia. Freshwater fishes of Saudi Arabia and adjacent regions of the Arabian Peninsula. Fauna of Saudi Arabia 5: 568-636.

Krupp F. 1985. Systematik und Zoogeographie der Süsswasserfische des levantinischen Grabenbruchsystems und der Ostküste des Mittelmeers. Dissertation, Johannes Gutenberg Universität, Mainz, 215 pp.

Kuyumcu M. 2019. Turkiye tatlisularindaki dislisazancik Aphanius Nardo 1827 (Actinopterygii: Cyprinodontidae) filogenisi. [in Turkish] Master thesis Rize

Lavergne E. 2012. Estuarine fish biodiversity of Socotra island (N.W. Indian Ocean): from the fish community to the functioning of Terapon jarbua populations. Biodiversity and Ecology Universitéde Bretagne occidentale - Brest 214 pp.

Marčić Z., Ćaleta M., Buj I., Zanella D., Mustafić P., Mihinjač T. \& Mrakovčić M. 2015. New records of Aphanius fasciatus (Valenciennes 1821) along the eastern coast of the Adriatic Sea in Croatia. Croatian Journal of Fisheries 73: 124-127.

Melhaoui M. 1994. Ecologie des ressources halieutiques des eaux continentales à interêt économique: Anguillidae Salomonidae. Thèse Doc. Es Sciences Oujda 163.

Pellegrin J. 1921. Le poissons des eaux douces de l'Afrique du Nord Francaise, Maroc, Tunisie, Sahara. Mémoires de la Société des Sciences naturelles du Maroc. 1 (2), 1-216, 96 figs.

Reichenbacher B. \& Sienknecht U. 2001. Allopatric divergence and genetic diversity of recent Aphanius iberus and fossil Prolebias meyeri (Teleostei Cyprinodontidae) from Southwest and Western Europe as indicated by Otoliths. Geobios 34: 69-83. 
Reichenbacher B., Kamrani E., Esmaeili H.R. \& Teimori A. 2009. The endangered cyprinodont Aphanius ginaonis (Holly 1929) from southern Iran is a valid species: evidence from otolith morphology. Environmental Biology of Fishes 86: 507-521.

Reichenbacher B., Sienknecht U., Küchenhoff H. \& Fenske N. 2007. Combined otolith morphology and morphometry for assessing taxonomy and diversity in fossil and extant killifish (Aphanius, Prolebias). Journal of Morphology 268: 898-915.

Teimori A., Motamedi M. \& Hesni M.A. 2016. Fish morphology and mitochondrial phylogeny reveal translocations of a native Aphanius Nardo 1827 (Teleostei: Cyprinodontidae) in Iran. Iranian Journal of Ichthyology 3: 181-189

Teimori A., Schulz-Mirbach T., Esmaeili H.R. \& Reichenbacher B. 2012. Geographical differentiation of Aphanius dispar (Teleostei: Cyprinodontidae) from Southern Iran. Journal of Zoological Systematics and Evolutionary Research 50: 289-304.

Teimori A., Esmaeili H.R. Erpenbeck D. \& Reichenbacher B. 2014. A new and unique species of the genus Aphanius (Teleostei: Cyprinodontidae) from Southern iran: A case of regressive evolution. Zoologischer Anzeiger 253: 327-337.

Teimori A., Esmaeili H.R., Gholami Z., Zarei N. \& Reichenbacher B. 2012. Aphanius arakensis, a new species of tooth-carp (Actinopterygii, Cyprinodontidae) from the endorheic Namak Lake basin in iran. Zookeys 215: 55-76.

Teimori A., Esmaeili H.R., Hamidan N. \& Reichenbacher B. 2018. Systematics and historical biogeography of the Aphanius dispar species group (Teleostei: Aphaniidae) and description of a new species from Southern Iran. Journal of Zoological Systematics and Evolutionary Research 56: 579-598.

Teimori A., Motamedi M. \& Iranmanesh A. 2018. Comparative morphology of urohyal bone in brackish waterspecies of the genus Aphanius Nardo, 1827 in the Persian Gulf and Southeastern Mediterranean Sea basins (Teleostei:Aphaniidae). Mediterranean Marine Science 19: 356-365.

Triantafyllidis A., Leonardos I., Bista I., Kyriazis I., D. Stoumboudi M. T., Kappas I., Amat F. \& Abatzopoulos T.J. 2007. Phylogeography and genetic structure of the Mediterranean killifish Aphanius fasciatus (Cyprinodontidae). Marine Biology 152: 1159-1167. 
Turan D., Kaya C., Baycelebi E., Aksu I. \& Bektas Y. 2018. Description of Gobio fahrettini a new gudgeon from Lake Ilgın basin Central Anatolia (Teleostei: Gobionidae). Ichthyological Exploration of Freshwaters http://doi.org/10.23788/IEF-1073

Valdesalici S., Langeneck J., Barbieri M., Castelli A. \& Maltagliati F. 2015. Distribution of natural populations of the killifish Aphanius fasciatus (Valenciennes 1821) (Teleostei: Cyprinodontidae) in Italy: Past and current status and future trends. Italian Journal of Zoology 82: $212-223$.

Valdesalici S., Brahimi A. \& Freyhof J. 2019. First record of Aphanius almiriensis from Italy and notes on the distribution of Aphanius fasciatus (Teleostei: Aphaniidae). Journal of Applied Ichthyology 35: 541-550.

Van Neer W., Wildekamp R.H., Küçük F. \& Ünlüsayın M. 2008. The 1997-1999 surveys of the Anatolian fish fauna and their relevance to the interpretation of trade at Sagalassos. In: Degryse P. \& Waelkens M. (Eds.) Geo-and Bio-Archeology at Sagalassos and in its Territory. Leuven University Press Leuven pp. 299-323.

Villwock W. 1985. Contribution on natural hybrids between two valid species of Aphanius (Pisces: Cyprinodontidae) from Bardawil-Lagoon North Sinai Egypt. Rapports et Procès-Verbaux des Réunions Commission Internationale pour l'Exploration Scientifique de la Mer Méditerranée 29: 57-63.

Wildekamp R.H., Küçük F., Ünlüsayın M., \& Van Neer W. 1999. Species and subspecies of the genus Aphanius Nardo 1897 (Pisces: Cyprinodontidae) in Turkey. Turkish Journal of Zoology 23: $23-44$.

Yeğen V., Balık S., Bilcen E., Sarı H. M., Uysal R. \& Yağcı A. 2008. Fish species of streams in Denizli provinces and their distribution (Turkey). Journal of FisheriesSciences.com 2: 301-311.

Yeğen V., Balık S., Erdal B., Sarı H.M., Rahmi U. \& IIlhan A. 2007. Afyon Illi akarsularında yayılış gösteren balık türleri ve dağılımları [in Turkish]. Türk Sucul Yasam Dergisi Ulusal Su Günleri 3: 419-428.

Yılmaz F., Barlas M., Yorulmaz B. \& Özdemir N. 2006. A Taxonomical Study on the inland water fishes of Muğla. E.U. Journal of Fisheries \& Aquatic Sciences 23: 27-30.

Yoğurtçuoğlu B. 2018. A Reassessment of the conservation status of Aphanius sureyanus (Neu 1937) (Cyprinodontiformes: Aphaniidae) and the first data on its reproduction in captivity. Hacettepe Journal of Biology and Chemistry 46: 601-607 
Yoğurtçuoğlu B. 2019. Simultaneous reproduction of two killifish congeners in the highly alkaline lake Salda (Turkey). Marine and Freshwater Research 70: 1633-1642.

Yoğurtçuoğlu B. \& Ekmekçi F.G. 2017. New records of Kizilirmak Toothcarp, Aphanius marassantensis from Central Yesilirmak River Basin (Turkey). Turkish Journal of Fisheries and Aquatic Sciences 17: 205-208.

Yoğurtçuoğlu B. \& Freyhof J. 2018. Aphanius irregularis, a new killifish from south-western Anatolia (Cyprinodontiformes: Aphaniidae). Zootaxa 4410: 319-330 